CORRECTION

Check for updates

\title{
Correction: Comprehensive molecular profiling of UV-induced metastatic melanoma in Nme1/Nme2-deficient mice reveals novel markers of survival in human patients
}

M. Kathryn Leonard (D), Gemma S. Puts, Nidhi Pamidimukkala, Gautam Adhikary, Yili Xu (D), Eric Kwok, Yuxin Jin, Devin Snyder (D), Nicolette Matsangos (D), Marián Novak, Anup Mahurkar (D), Amol C. Shetty (D), Radomir M. Slominski, Edward C. De Fabo,

Frances P. Noonan (D), Chi-Ping Day (D), Mohammed Rigi, Andrzej T. Slominski, Michelle G. Webb (D), David W. Craig (iD, Glenn Merlino, Richard L. Eckert, John D. Carpten, Zarko Manojlovic (D) and David M. Kaetzel (D)

(c) The Author(s), under exclusive licence to Springer Nature Limited 2021

Oncogene (2021) 40:6394; https://doi.org/10.1038/s41388-021-02045-4

Correction to: Oncogene https://doi.org/10.1038/s41388-02101998-w, published online 25 August 2021

The wrong Supplementary file Tables was originally published with this article; it has now been replaced with the correct file.

The original article has been corrected.

\section{ADDITIONAL INFORMATION}

Supplementary Information The online version contains supplementary material available at https://doi.org/10.1038/s41388-021-02045-4.

Correspondence and requests for materials should be addressed to David M. Kaetzel. Reprints and permission information is available at http://www.nature.com/ reprints 